\title{
一自由面爆破におけるき裂およびクレータの 生成機構についての一考察
}

\author{
勝山邦 久 ${ }^{1}$ 佐 \&宏 ${ }^{2}$ \\ 伊 藤 一 郎 $^{3}$
}

\section{1. 緒言}

近年, 電子計算機の発達によつて破壊現象を逐次破壊 現象としてとらえ, 破壊の進展にともなら材料内の応力 状態の変化が解析されるようになつてきた。波動の伝播 にともなら材料の破壊に関しても，ラグランジュ座標で 表示した運動方程式を差分近似を用いて解くという手 法 ${ }^{1)}$ を用いて，爆源近傍の破壊の様相や一自由面爆破の 場合の破壊圈の大きさを破壊を考慮した応力解析結果か ら推定しようとする研究が行なわれている ${ }^{23)}$ 。

そこで今回は，この手法を用いて，まず材料の破壊を 考慮しない場合に一自由面爆破の際に媒質内に生ずる応 力状態を求め, その結果と材料内の応力状態が三つの波 動による応力の合成值であると考えて求められた応力解 析結果とを対比して検討し，ついで破壊を考慮した応力 解析を行なつてき裂の成長過程を推定し, その推定した き裂の進展状況と実際に実施した小規模の爆破試験によ つて生成したき裂の様相とを対比するとともに，さらに 破断面上に生成するリップルマークの生成機構をシミュ レーションの結果を用いて検討したので, それらの結果 について報告する。

\section{2. 動的応力の解析方法の概略}

今回採用した動的応力の解析方法は, G. Maenchen と S. Sack によつて示されている “Tensor Code”を少し 修正したものであつて，その概念は第 1 図に示すように ある時間 $\left(t=t_{0}\right)$ に材料内に存在している応力場にラグラ ンジュ座標系で示された運動方程式を適用し，これを差 分近似を用いて解いて $t=t_{0}$ 時間に対応する材料内の各 点（ラグランジュ座標の節点）における変位加速度を求 め，これを $\Delta t$ なる微小な時間間隔で 2 回積分することに より $t=t_{0}+\Delta t$ 時間における各節点の変位を求め, つい でラグランジュ座標で囲まれている要素内のひずみをそ れを取り囲んでいる四つの節点の変位より求め，そのひ ずみに材料の状態方程式を適用して $t=t_{0}+\Delta t$ 時間に対 応する材料内の応力状態を算出するといらょうに，第 1

\footnotetext{
* 1972年 4 月 15 日受理

1. 正会員 京都大学大学院学生

2. 正会員 工博，京都大学工学部講師
}

3. 正会員 工博 京都大学工学部教授
図に示したループを材料内の各点について $\Delta t$ なる時間 間隔で回すことによつて応力波の伝播にともなう動的応 力を算出するという方法である。

\section{3．破壊を考慮しない場合の応力状態}

\section{$3 \cdot 1$ 数值解析に用いた条件}

上記の方法老用いて，一自由面爆破の際に媒質内に生 ずる応力状態を解析するためには，その媒質をラグラン ジュ座標 $(k, l)$ で区切られた数多くの四辺形要素に分割 する必要がある。そこで今回は第 2 図に示すような要素 分割を用い，さらに問題の対称性を利用して媒質の $1 / 2$ の 部分のみについて平面ひずみの問題として解析を行なつ た。したがつて, 応力解析は円柱状の長装薬を用いたべ ンチカット爆破の場合とほぼ同じ条件で行なつたことに なる。想定した模型は，アクリル酸樹脂板を 1 号電気雷 管を用いて衝撃した場合に生成するき裂の様相と計算結 果とを対比して検討するために，第 2 図に示した点 $\mathrm{P}$ を 中心とする内圧が作用する円柱孔の半径を, $0.60 \mathrm{~cm}$, 点 $\mathrm{P}$ から自由面までの距離，すなわち最小抵抗線 $(W)$ の 長さを $2 \mathrm{~cm}$, 正方形の部分の四辺形要素の一辺の長さを $0.42 \mathrm{~cm}$ とした。模型の大きさはよこメたてが約 $40 \mathrm{~cm} \times$ $25 \mathrm{~cm}$ であるので，今回の場合は，爆破によつてクレー タが生成してしまうまでに自由面以外の端面からの反射 波によつて媒質内の応力状態が影響されることはない。 四辺形要素数は約 6,000 , 時間間隔 $\Delta t$ は $1 \mu \mathrm{sec}$ であつて, 80 回繰り返して $t=80 \mu \mathrm{sec}$ ま゙計算するのに必要な計算 時間は約770秒である。上記のように，き裂の成長過程 をシミュレートするために，模型の弾性定数はメタアク リル酸樹脂の值を用いた。すなわち，縦波の伝播速度は

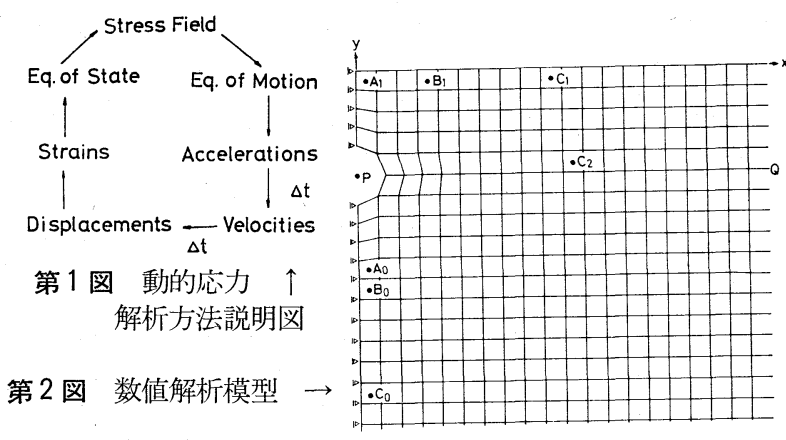

日本鉱業会誌/88 $1014(' 72-8)$

$465\langle 11\rangle$ 
$3.0 \times 10^{3} \mathrm{~m} / \mathrm{sec}$, 横波の伝播速度は $1.2 \times 10^{3} \mathrm{~m} / \mathrm{sec}$, 密 度は $1.2 \mathrm{~g} / \mathrm{cm}^{3}$ である。また引張強度は $7.5 \times 10^{2} \sim 1.0 \times$ $10^{3} \mathrm{~kg} / \mathrm{cm}^{2}$ であるので今回はとりあえず $9.0 \times 10^{2} \mathrm{~kg} /$ $\mathrm{cm}^{2}$ という值を採用して応力解析を行なうことにした。

円柱孔 $\mathrm{P}$ の内壁には, (1)式で示されるパルス的な変 化をする圧力を作用させた。

$$
P(t)=P_{0} N\left(e^{-\alpha t}+e^{-\beta t}\right)
$$

ただし, $P_{0}$ は圧力最高值, $N$ は定数, $\alpha, \beta$ は圧力波形 を定める定数， $t$ は時間である。なお， $P_{0}, \alpha, \beta$ の值は 爆源から $4 \mathrm{~cm}$ の位置における応力状態が 1 号電気雷管を 用いて試料を衝撃した場合に発生した粒子の変位速度な どの実測結果を用いて算出した応力状態とほぼ同一とな るように定めた。

\section{$3 \cdot 2$ 応力解析結果}

まず，自由面が存在しないと仮定した場合に，爆源か $ら 4 \mathrm{~cm}$ の距離の点に生ずる接線方向の主応力 $\sigma_{\theta}$ の時間的 変化状態を示したのが第 3 図である。第 3 図には比較の ために厚さ $18 \mathrm{~mm}$ のアクリル酸樹脂板に設けられた直径 $7 \mathrm{~mm}$ の装薬孔内で 1 号電気雷管を爆轟させた場合に材 料内に生ずる応力状態を材料粒子の変位速度などの実測 結果に弾性理論 ${ }^{5}$ を適用することによつて算出した結果 を点線で示しておいた。第 3 図に示した $\sigma_{\theta}$ の時間的変化 状態において周波数などは両者ともほぼ同一であるが， $\sigma_{\theta}$ の最高值はいく分異なつている。これはこの解析では 媒質を完全弾性体として解析を行なつたために応力波の 伝播にともなら減衰指数が 9.98 となり, 現実の減衰指数 (1.42)に比較して小さいためである。

つぎに，このような応力波が爆源から投射された場合

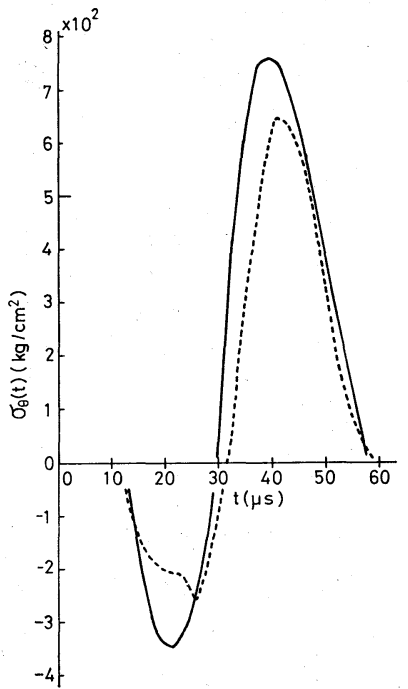

第3 図

爆源から $4 \mathrm{~cm}$ の点に生ず る $\sigma_{\theta}$ の時間的変化状態

に，自由面が存在する媒質内ではどのような応力状態に なるかを，等最大主応力線を用いて各時間ごとに示した のが第 4 図であつて, 引張応力は点線で圧縮応力は実線 で示してある。第 4 図( b ) に示すように，t=10 $\mathrm{sec}$ に なると, 装薬孔周辺に引張応力が生じ始め, 最小抵抗線 近傍の応力状態は自由面からの反射波によつて大きく乱 れ始める。その結果, 最小抵抗線と自由面との交点近傍 にも小さな值ではあるが引張応力が生じ始める。 $t=15 \mu$ sec では, 装薬孔周辺および自由面近傍で応力が引張応 力となる範囲が急速に拡がっている。いま引張応力とし て $2 \times 10^{3} \mathrm{~kg} / \mathrm{cm}^{2}$ あるいは $1 \times 10^{3} \mathrm{~kg} / \mathrm{cm}^{2}$ を示す等最大主 応力線についてみてみると, 最小抵抗線加ら少し離れた 点ではこの等最大主応力線が自由面により近くまでのび
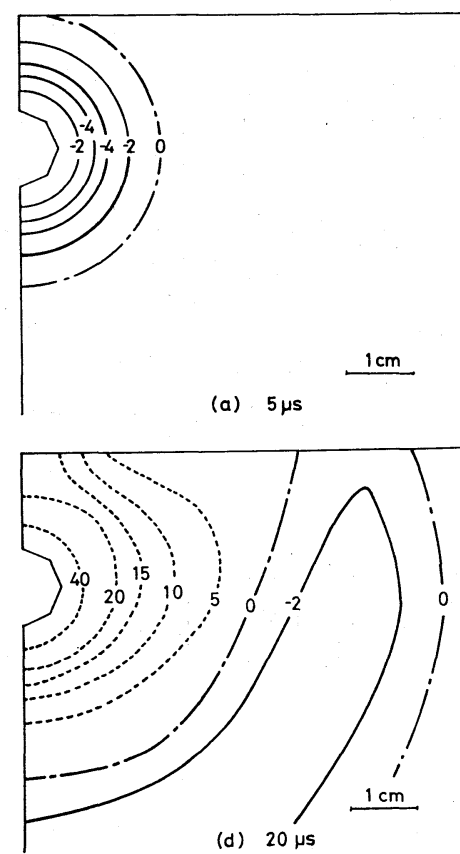

(d) $20 \mu \mathrm{s}$

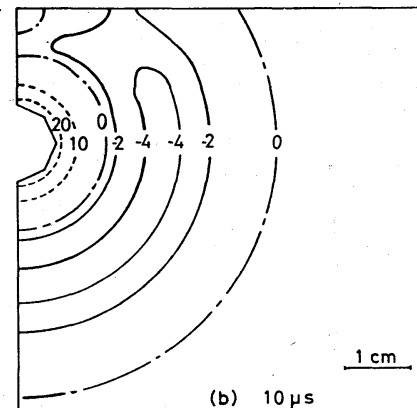

(b) $10 \mu \mathrm{s}$

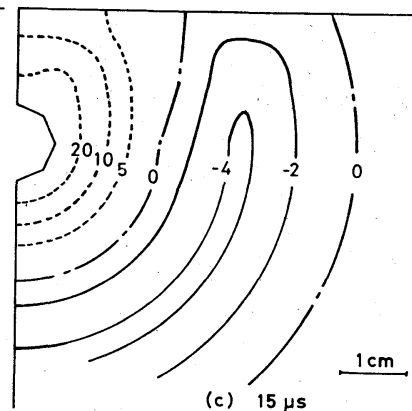

(c) $15 \mu \mathrm{s}$

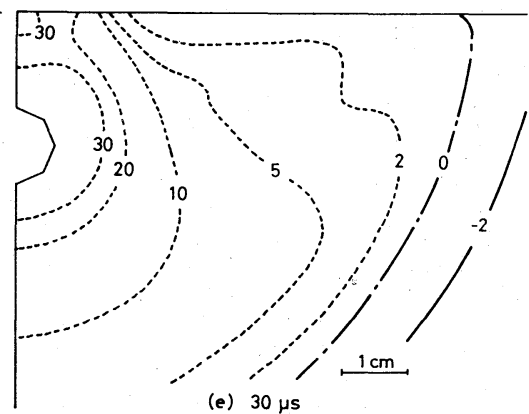

(e) $30 \mu \mathrm{s}$

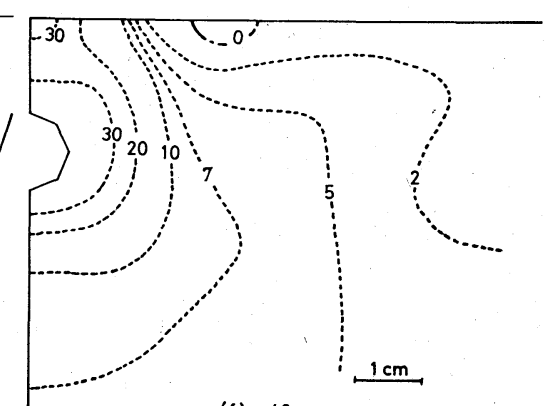

(f) $40 \mu \mathrm{s}$

第4 図 等最大主応力線図 (数字: $\times 10^{2} \mathrm{~kg} / \mathrm{cm}^{2}$ ) 
ている。このことは興味あることであつて，自由面で反 射した応力波と装薬孔から投射された応力波との干渉に よつてこのような状態が生じたものと考えられる。なお このような傾向はさきに実施した応力解析結果 ${ }^{6}$ ) でもみ とめられる。 $t=20 \mu \mathrm{sec}$ では, 最小抵抗線と自由面との 交点近傍に引張応力の集中がみられ, また, 自由面上で は $x<2 W$ の広い範囲で引張応力となつているが，W $<x<2 W$ では引張応力の值は小さく, 自由面から応力 が解放されやすいことを示している。したがつて， $x>$ $W の$ 範囲では自由面上よりはむしろ自由面から離れた第 2 図に示した $\mathrm{P} \mathrm{Q}$ 線上の近傍で引張応力が大きくなつて いる。 $t=40 \mu \mathrm{sec}$ となると, 自由面上の $x \fallingdotseq 1.5 \mathrm{~W}$ 近傍 で小さな絶対值ではあるが圧縮応力が現われてくる。こ れ以後は波動のピークは爆源から離れて行き, 媒質内の 応力の絶対值は小さくなつていく。

第 5 図( a ), ( b ) そ, それぞれ $t=15 \mu \mathrm{sec}$ および $t=$ $30 \mu \mathrm{sec}$ における最大主応力が作用する面の方向を示し た図であつて，もし引張破壊によるき裂が生ずるとすれ ばこの面に沿つて生ずるものと考えることができる。第 5 図( a )に扔いて，1点鎖線で示した曲線はこの時点で の波頭の位置を示したものであつて, 自由面と破線で囲 まれた部分は自由面からの反射波の影響を受けている部 分, 破線と 1 点鎖線で囲まれた部分はまだ反射波の影響 安受けていない部分である。第 5 図( b ) に示した $t=30 \mu$ sec では, 図に示した部分はすべて反射波の影響を受け ており,この時点になれば, 最小抵抗線よりかなり離れ た自由面近傍の各点での最大主応力の作用する面の方向 に特異性がみられるようになる。

第 6 図( a ), ( b ), ( c ) は, それぞれ自由面の影響を著 しく受けると考えられる第 2 図に示した点 $A_{1}$, 点 $B_{1}$ お よび点 $\mathrm{C}_{1}, \mathrm{C}_{2}$ における主応力の時間的変化状態を示した 図であるが,さらにこれらの図には比較のために, 自由
面の影響が少ないと考えられる点 $\mathrm{A}_{0}, \mathrm{~B}_{0}, \mathrm{C}_{0}$ における主 応力の時間的変化状態をも示しておいた。なお, 点 $\mathrm{A}_{0}$ と 点 $\mathrm{A}_{1}$, 点 $\mathrm{B}_{0}$ と点 $\mathrm{B}_{1}$, 点 $\mathrm{C}_{0}$ と点 $\mathrm{C}_{1}, \mathrm{C}_{2}$ はいずれも爆源から 等距離に選んだ点である。これらの図において, 主とし て引張応力として作用する主応力を $S_{1}$, 圧縮応力として 作用する主応力を $S_{2}$ とする。第 6 図( a ) より，点 $\mathrm{A}_{1}$ に生 ずる $S_{1}$ の最大值は点 $\mathrm{A}_{0}$ に生ずる $S_{1}$ の最大值の約 2 倍と なつていることがわかる。また，第 6 図 $(\mathrm{b})$ より，点 $\mathrm{B}_{1}$ に生ずる $S_{1}$ の最大值は点 $\mathrm{B}_{0}$ に生ずるそれより小さいが, 引張応力として作用する時間は点 $\mathrm{B}_{1}$ の方が点 $\mathrm{B}_{0}$ よりも長 いことがわかる。第 6 図( $\mathrm{c}$ )より, 点 $\mathrm{C}_{1}$ に生ずる $S_{1}$ は点 $\mathrm{C}_{0}$ に生ずる $S_{1}$ に比べて早い時間で引張応力となるが， $S_{1}$ の引張応力の最大値は小さく, またすぐ圧縮応力とな る。このことは点 $\mathrm{C}_{1}$ 近傍では引張破壊が発生しにくい傾 向を示すものと考えられる。また, 自由面近傍の点に生ず る $S_{2}$ の最大值は自由面から離れた点に生ずる $S_{2}$ の最大值 よりも小さい。以上の結果と第 4 図および第 5 図に示し た結果をあわせ考えれば自由面近傍において, 最小抵抗 線の近くでは引張主応力は大きな值を示ずが， $x>W$ の 範囲では引張主応力は小さくなり, 引張破壊は発生しに くくなるものと思われる。以上に, 一自由面爆破の場合 に材料内に発生する動的応力状態を差分近似を用いて解 析した結果を示したが，これらの結果はすべて材料内の 動的応力は爆源から投射された縦波とその縦波が自由面 で反射して生成する反射縦波および反射横波の三つの応 力波による応力の合成值であると考えて求められた応力 解析結果 ${ }^{7)}$ とよく一致している。そこでつぎに材料の破 壊を考慮した応力解析を実施してき裂の成長状況につい て検討することにした。

\section{4. き裂の成長過程のシミュレーション}

爆轟衝撃に起因する応力波の伝播にともなう材料の破
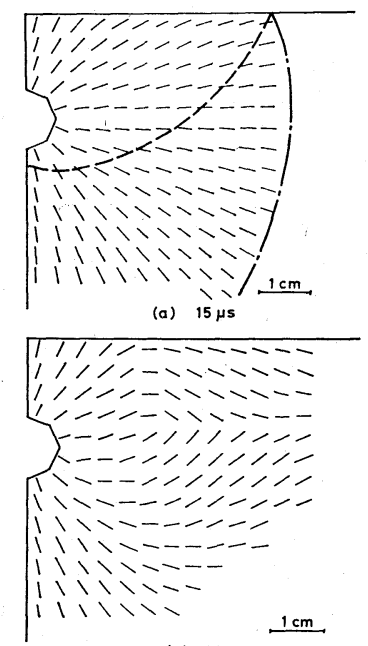

(b) $30 \mu \mathrm{s}$

第 5 図 最大主応力が作用 する面の方向

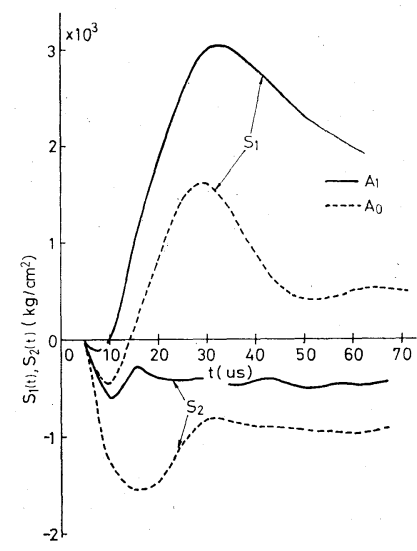

(a) 点 $\mathrm{A}_{1}, \mathrm{~A}_{0}$ の場合

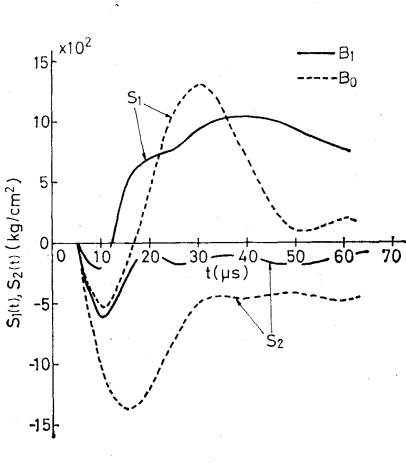

(b) 点 $\mathrm{B}_{1}, \mathrm{~B}_{0}$ の場合

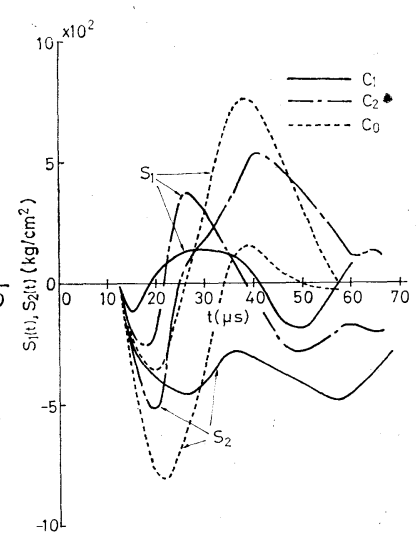

(c) 点 $\mathrm{C}_{1}, \mathrm{C}_{2}, \mathrm{C}_{0}$ の場合

第6 図 主応力 $S_{1}, S_{2}$ の時間的変化状態 
壊の形態としては, 降伏またはせん断破壞打よび引張破 壊が存在し, 降伏または, せん断破壊圈は爆源のごく近 傍に発生し, その外側に引張破壊圈が発生する ${ }^{2}$ 。しか しここでは破壊圈の外周を規定する引張破壊に注目して 応力解析を行ならことにしたので, 降伏またはせん断破 壞は考慮しなかつた。材料の引張破壊を応力解析に導大 する方法としては種々の方法が考えられるが，今回はと りあえず四辺形要素内の最大主応力 $\sigma_{1} か ゙ t=t_{c}$ で引張強 度 $S_{t}$ に達した後は $\sigma_{1}$ が作用していた面に生ずる引張の直 応力 $\sigma_{1 n}$ が直線的に減少し $t=t_{c}+5 \mu \mathrm{sec}$ で零となるよう にした。すなわち, $t=t_{c}$ で $\sigma_{1} \geqq S_{t}$ となつた要素の值を まず $\sigma_{1}{ }^{\prime}=0.9 S_{t}$ とし, 最小主応力 $\sigma_{2}$ の値を改めて $\sigma_{2}{ }^{\prime}=$ $\sigma_{2}+\left\{-\lambda\left(\sigma_{1}-0.9 S_{t}\right) /(\lambda+2 \mu)\right\}$ として次の時間サイク ルの応力計算を実施し, $t \geqq t_{c}+10 \Delta t$ の時間で $\sigma_{1 n}$ の值 が正の場合には改めて $\sigma_{1 n}{ }^{\prime}=0$ とし， $\sigma_{2 n}$ の值を改めて $\sigma_{2 n}{ }^{\prime}=\sigma_{2 n}+\left\{-\lambda \sigma_{1 n} /(\lambda+2 \mu)\right\}$ とし, $\sigma_{1 n}$ が負の場合に は，そのままの值にして打くこととした。ここで， $\sigma_{1}{ }^{\prime}$, $\sigma_{2}{ }^{\prime}, \sigma_{1 n^{\prime}}{ }^{\prime}, \sigma_{2}{ }^{\prime}{ }^{\prime}$ は補正された応力である。したがつて, $t \geqq$ $t_{c}+10 \Delta t$ ，才なわち，破壊を考慮した場合は $\Delta t=0.5 \mu \mathrm{sec}$ であるため, $t \geqq t_{c}+5 \mu \mathrm{sec}$ の時間では, $t=t_{c}$ で最大主 応力が作用していた面には, 引張の直応力は生じないこ とになる。以上のようにして破壞現象を計算に組み入れ ることによつて破壊を考慮した応力計算を実施した。な お，破壞した要素の弾性定数は破壊しない場合の定数と 同じものを用いた。まず，第7図に実線で示した曲線は 引張破壊を発生させっつ伝播してきた応力波によつて第 2 図にC 的な変化状態を示したものであり，比較のために材料粒
子の変位速度, 変位などの実測結果に弹性理論を適用す ることによつて算出した結果を点線で示して扔いた。こ のように試料を 1 号雷管で衝撃した場合に得られた変位 速度などの実測結果を用いて算出した応力状態と実測結 果を用いずに上記の解析を用いて算出した応力状態とが ほぼ一致するといらことは，今回実施した応力解析によ つて実際に爆破を行なつた場合に材料内に発生する応力 状態が適確に解析されているといらことを示しており， 以後に説明する破壊のシミュレーションの結果の妥当性 を裏ら゙けているものと考光られる。

第 8 図は, 装薬孔壁面から成長する半径方向のき裂の 先端（要素内の主応力が仮定した引張強度に達したとき その要素にき裂の先端が到達したと考えた）が，爆轟後 ある時間でどこまで進展するかを示した図であつて，た とえば，第 8 図( b ) には $t=15 \mu \mathrm{sec}$ および $t=20 \mu \mathrm{sec}$ の 場合のき裂の先端の位置が実線で示してあつて，破線は （a）における $t=10 \mu \mathrm{sec}$ の場合のそれである。図より 明らかなように, $t=10 \mu \mathrm{sec}$ では爆源から放射状に生成 するき裂の先端は, 爆源からの距離 $r$ が約 $1 \mathrm{~cm}$ のとこ ろまで成長している。 $t=15 \mu \mathrm{sec}$ では, 自由面の影響に よつて自由面に近い方のき裂の進展は他の方向のそれよ りも卓越し， $t=20 \mu \mathrm{sec}$ では自由面方向に進行したき裂 は自由面に達しているが，他の方向へのき裂の先端はま だ $r=1.6 \mathrm{~cm}$ の位置にしか達していない。 $t=25 \mu \mathrm{sec}$ で 注目すべき点は, 自由面近傍の $x<W$ の範囲の破壊がほ ぼ終了してしまつていると同時に, き裂の先端を結ぶ曲 線がこの時間までは比較的滑らかな曲線であつたのが凹 凸のある曲線になつてきたことである。すなわち, $t<25$

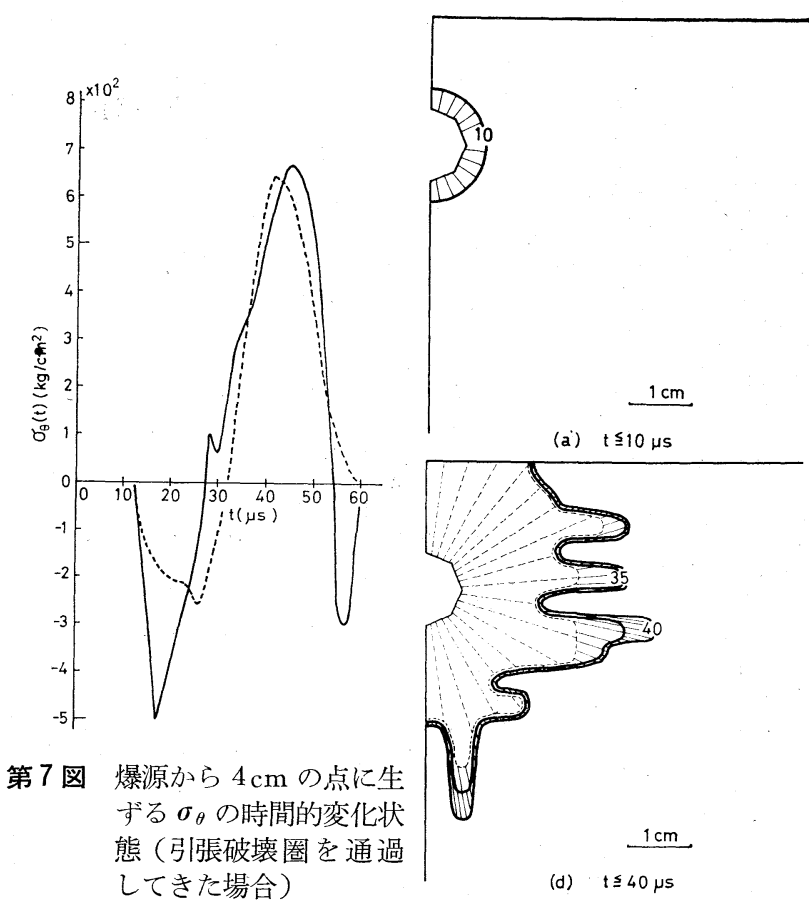

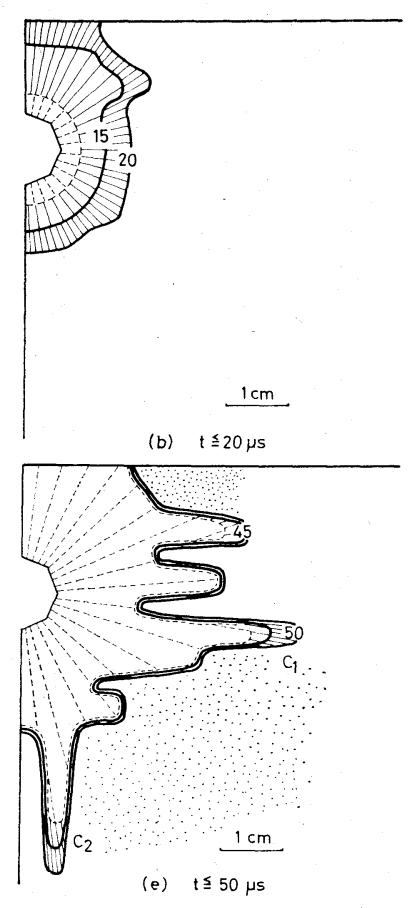

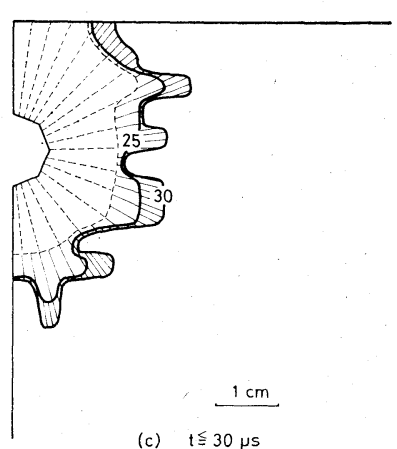

(c) $\mathrm{t} \leqq 30 \mu \mathrm{s}$

第8 図 き裂の成長過程のシミュレー ション

$468\langle 14\rangle$ 
$\mu \mathrm{sec}$ では自由面近傍を除いたすべての方向でほとんど 同じ程度にき裂が成長してきたが， $t=25 \mu \mathrm{sec}$ 頃から, そ のまま成長するき裂と, 成長の程度が遅くなるき裂とに

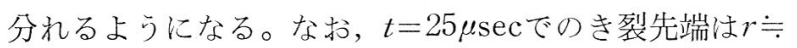

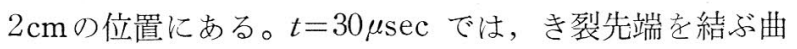
線の凹凹の傾向はさらに強くなり，これ以後にき裂が成 長する方向が暗示される。そして $t \geqq 30 \mu \mathrm{sec}$ では第 2 図 に示した P Q方向および最小抵抗線と逆の方向の三つの 方向へき裂は成長するようになり，第 8 図(e)に点点で 示した部分にはき裂は生成しない。今回は，き裂内への ガスの進入を考慮しなかつたが，このガス压の作用を考 慮すれば $\mathrm{P} Q$ 方向および最小抵抗線と逆の方向に生成し たき裂はさらに成長するであろらし，ガスの進入する程 度やガスがどのき裂に進入するかによつては，P Q 方向 に成長したき裂はさらに自由面方向に向つて成長する場 合も生じ大きなクレータを形成することもあるであろ う。なお，最小抵抗線と逆の方向に成長したき裂は，本 来ならば対称軸上に生成するべきものと考えられるが， 今回の計算に用いた要素分割が粗いためと, 装薬孔が八 角形をしているためにすこし対称軸から離れて生成した ものと思打れる。

第 8 図( e )上り明らかなように, 爆源近くでは放射状 に生成したき裂の数は多く, 爆源から離れるにしたがつ て，き裂の数は少なくなつていくという現象が，この解 析結果で明膫に示されて㧍り, 少なくなつていく程度は $r \fallingdotseq 2 \mathrm{~cm}$ 頃から顕著となつている。爆源から離れるにし たがつてき裂の数が少なくなる大きな要因の一つに，破 壊をともなつて伝播する波動の伝播距離が長くなるにつ れて波長が順次長くなることがあげられるであろら。す なわち，第 9 図は，主として接線方向に作用する主応 力 $S_{1}$ が引張态力として作用しはじめてから引張強度に達 するまでの時間 $T$ を縦軸に, 爆源からの距離 $r$ を横軸に とつて両者の関倸を示したものであつて，これより，爆 源から離れるとともに, 被壊するまでに要する時閒が大 きくなることがわかる。

第10図は，数值解析を行なつた条件とほぼ同じと考え られる条件でアクリル酸樹脂板を用いて実験を行なつた

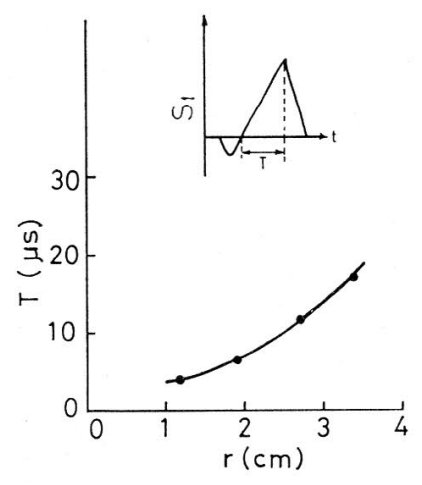

第 9 図

き裂在生成しながら伝播す る応力波の伝播距離と引張 破壊が生成するまでの洔間 との関係

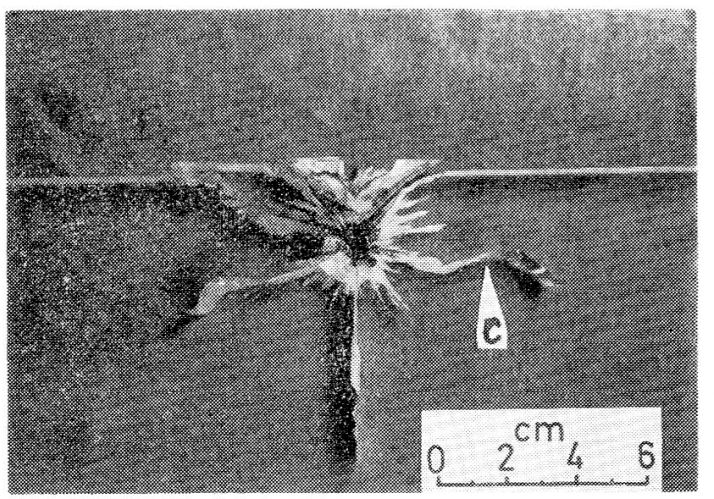

第10図 一自由面爆破によつて生成した破壞の様相の一例

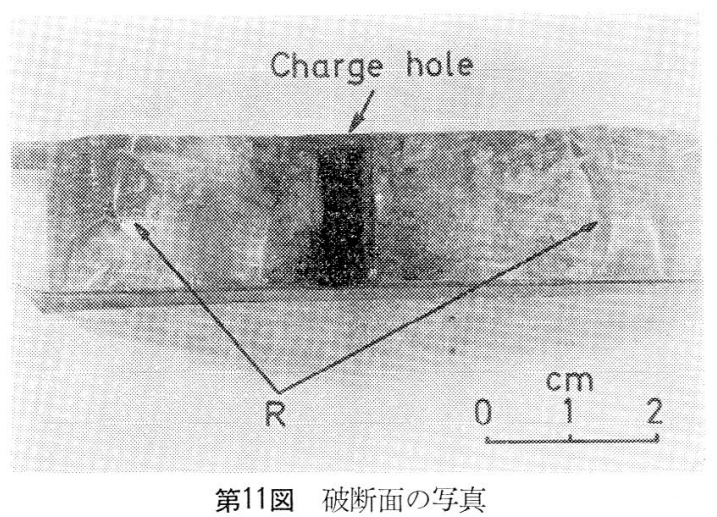

場合に生じたき裂の様相を示した写真である。第 8 図お よび第10図老比較することによつて数值解析によるシミ ニレーションで推定したき裂の成長の様相と，実験によ つて生成したき裂の様相とは，かなりよく一致している ことがわかる。

\section{5. 破断面上に現われるリップルマークについて}

第10図より，大きな数本のき裂のいすれにしても爆源 加ら $r \fallingdotseq 2.5 \mathrm{~cm}$ 程度まではほぼ直線的に成長しており, $r \fallingdotseq 2.5 \mathrm{~cm}$ の近傍で第 1 回目の曲折があるのがわかる。 そこで，例として第10図にCで示したき裂をとりだし， その破断面を観察してみると，第11図にRで示したよう に $r \fallingdotseq 2.5 \mathrm{~cm}$ の近傍に波打つたような模様がみられる。 この模様がリップルマークと呼ばれていることはよく知 られており，その生成機構についても一，二の考察がす

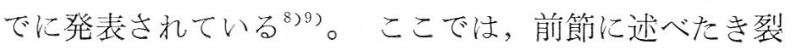
の成長過程のシミュレーションの結果からリップルマー クの生成機構を検討してみよう。第 8 図 $(\mathrm{e})$ に $\mathrm{C}_{1}, \mathrm{C}_{2}$ で 示したき裂において， $\mathrm{C}_{1}$ では $t \leqq 30 \mu \mathrm{sec}$ の範囲， $\mathrm{C}_{2}$ で は $t \leqq 20 \mu \mathrm{sec}$ の範囲ではき㳖は同じ程度の速度で成長 し，その時のき裂の先端は $\mathrm{C}_{1}$ では $r \fallingdotseq 2.4 \mathrm{~cm}, \mathrm{C}_{2}$ では $r \fallingdotseq 1.6 \mathrm{~cm}$ まで達している。ところが， $\mathrm{C}_{1}$ では $t$ が39〜 $35 \mu \mathrm{sec} ， \mathrm{C}_{2}$ では $\begin{array}{r} \\ \end{array}$ の2 倍の速度で成長しており，それ以後はまたもとと同 じ速度にもどつている。このように，rが2 3 $\mathrm{cm}$ の付 
近でき裂が成長する速度は速くなり，この位置は第11図 にRで示したリップルマークの位置と一致している。こ のことから，き裂の先端が成長する速度が急激に大きく なるとその点にリップルマークが生成するのではないか と思われる。また，成長が停止していたき裂に再び外力 を加え，そのき裂を成長させた時，古いき裂と新しく生 成したき裂の境界にリップルマークが生成することは容 易に実験から得られる結果である。以上のことから，き 裂の先端が成長する速度が停止しているか，またはある 速度で成長している状態から，さらに大きな速度でき裂 が成長する状態に移行すると，その点にリップルマーク が生成するものと思われる。

\section{6. 結言}

この研究では，まず，ラグランジュ座標系で表示した 運動方程式を差分近似を用いて解くことにより波動によ る動的応力を解析するという方法を用いて，广クリル酸 樹脂を一自由面で爆破した際の応力状態を解析した。そ の結果, 自由面近傍における応力状態の特徵の一つとし て, 最小抵抗線近傍に生ずる引張応力は自由面がないと 仮定した場合に比べて大きな值を示すこと，また最小抵 抗線から少し離れた $x<W の$ 範囲内に生ずる引張応力の 值は，自由面がないと仮定した場合に比べて小さくなる が，引張りとして作用する時間は長くなり，さらに $x>$ $W$ の範囲では引張応力の值も 小さくなるとともに引張 りとして作用する時間も短くなることなどを明らかにし た。

つぎに，引張破壊を考慮に入れた解析を行なつてき裂 の成長過程をシミュレートし，実験によつて得られたき 裂の様相およびクレータの形と比較検討した。その結果
実験によつて得られたき裂の様相とクレータの形を数值 計算によりある程度シミュレートすることができたが， それによれば，まず爆源近傍では数多くのき裂が生成し， 爆源から離れるにしたがつて，放射状に生成したき裂の 数は減少することがあげられる。そして，アクリル酸樹 脂を用いた一自由面爆破によつて生ずる引張破壊は，ま ず最小抵抗線近傍に生じ，すべての方向に $r \fallingdotseq W の$ 範囲 内で引張破壊が生成するころには自由面近傍の $x<W$ の 範囲での破壊はすでに終了している。それ以後は $\mathrm{P} \mathrm{Q}$ 方 向拉よび最小抵抗線と逆の方向にき裂は大きく成長し， ガス圧の作用の仕方あるいはどのき裂にガスが進入する かによつて $\mathrm{P} Q$ 方向に伸展したき裂は自由面に達し大き なクレータを形成する場合も考えられる。

さらに，破断面上に生ずるリップルマークの生成機構 についてシミュレーションの結果から検討し，リップル マークはき裂の成長する速度が停止しているか，または ある速度で成長している状態からさらに大きな速度で成 長する状態に移行する点に生成するものと思われること を示した。なお，この研究の数值計算に用いた電子計算 機は京都大学大型計算機センターの FACOM 230-60 で あることを付記しておく。

\section{参考文 献}

1) G. Maenchen, S. Sack: Methods in Computational Physics, Vol. 3 p. 181

2) 佐々宏一・伊藤一郎：材料, 21 卷 221 号 (昭47) 123頁

3) J. T. Cherry: Int. Rock Mech. Min. Soci. Vol. 4 (1967)

4) 交献 1$)$

5) 伊藤一郎・佐々宏一：日本釷業会誌, 79巻898号 (昭38), 261 頁

6 ）伊藤一郎・佐々宏一：工樂火薬協会誌，29巻 4 号(1968) 274頁

7) 交献5),6)

8) J. B. Murgatroyd: J. Soc. Glass Tech., 26 (1942), p. 156

9) 和田八三久編 : 力学物性, 共立出版祄: (昭43), 324頁

\title{
Formation of Cracks and Crater Caused by a Blasting with One Free Face
}

\author{
by Kunihisa KATSUYAMA, Koichi SASA and Ichiro ITO
}

The dynamic stresses in a material caused by a blasting with one free face have been analysed with the aid of a numerical technique which involves the finite-difference approximation to the momentum equation, and then, the processes of the crack and crater formation caused by the blasting have been simulated. The main results obtained are as follows;

1) The results of the simulations of the crack and crater formation obtained by this numerical analysis agree fairly well with the experimental results. (Fig. 8 and Fig. 10) At first, cracks are produced near the line of least resistance, and in the next time cracks are produced near the free face in the range of $x<W$ and lastly the crack which is produced in the direction of $\mathrm{PQ}$ grows toward the free face.

2) It is presumed by using the results of the simulation of cracks that the ripple marks on the surfaces of cracks are produced at the point where the tip of moving crack stops for a while and then starts to move again or at the point where the growing rate of the tip increases suddenly. (Fig. 8 and Fig. 11) 